For citation:

Izvestiya Ural'skogo gosudarstvennogo gornogo universiteta [News of the Ural State Mining University]. 2016. Issue 2. pp. 54-58.

удк 622.553. 669.21(479.24)

DOI 10.21440/2307-2091-2016-2-54-58

\title{
SELECTION OF OPTIMAL DEVELOPMENT SYSTEMS FOR “GOSHA” GOLD DEPOSIT IN THE REPUBLIC OF AZERBAIJAN
}

\author{
Z. J. Afandiyeva, M. B. Osmanov
}

\section{Выбор эсрсективных систем разработки Аля Гошинского золоторудного месторожления (Азербайджанская республика)}

\section{3. Аж. Эсенниева, М. Б. Османов}

В 1966 г. на Гошинском золоторудном месторожцении были проведены первые геологоразведочные работы и выявлено 6 рудных зон. В последуюшие годы проводились детальные геологоразведочные работы, в результате которых выявлено и изучено 17 зон. С 2009 г. месторожцение разрабатывается международной горнорудной компанией, которая Аоказама, что зоны 13 и 13а являются высокоперспективными, с богатым золоторудным оруденением. Проведенные исследования системы разработки подтвердили, что в условиях Гошинских золоторудных месторожљений требуется применение конкретных систем разработки, которые наиболее полно отвечают природным и техногенным условиям месторожАения. Аля эксплуатации месторожцений были рассмотрены различные системы разработки, большинство из которых являются традиционными, некоторые - новые. С учетом всех необходимых критериев и горнотехнических условий премлагается система разработки Гошинского месторожАения, предполагаюшая скважины с открытыми забоями и отбойку руды гмубокими шпурами сверху вниз. В статье Ааны результаты SWOT-анализа премложенной системы разработки. В настоящее время разработка с применением премложенного способа уже начинается. Преможенные варианты системы разработки имеют свои преимушества по сравнению с Аругими: они позволяют сэкономить начальные капитальные затраты и предусматривают снижение объема горных работ (не требуют заполнения разработанной пустоты). Премложенные авторами варианты систем разработки Гошинского золоторудного месторожАения могут быть применены мял Аругих рудных месторожАений Азербайджана и соседних республик с аналогичными горнотехническими и геологическими условиями.

Киючевые слова: золоторудное месторожцение; подземные разработки; горные работы; системы разработки; рудная минераяизация; капитаяьные затраты.

In 1966, "Gosha" gold mine hosted its first geological exploration works and six ore zones were found. In subsequent years, scientists carried out detailed exploration resulting in 17 known and studied zones. Since 2009, international mining company develops this deposit, and it proved that the areas 13 and 13a are mega-rich with gold ore mineralization.

Implemented investigation of the development system confirmed that Gosha gold mine requires concrete development system that can fully meet natural and technical conditions of the deposit.

We studied different development systems for the development of the deposit and gave their outcome in the article. Considering the main criterions and factors necessary for choosing development system, we propose the system "Wells with open face, breaking of ore by blast holes, from the top to bottom". Strong and weak features, opportunities and dangers of the offered development system and the results of the SWOT analysis one can find in the article.

In comparison with others, the proposed variant of the development system has the following properties: it allows saving initial economic losses, and it decreases volume of mining works (filling the developed gaps is not required)

Our proposed options for development systems Goshinsky gold deposit fully meet the conditions of natural and technological fields and can be applied to other ore deposits of Azerbaijan and neighboring countries with similar mining and geological conditions.

Keywords: gold deposit; underground development; mining operations; development systems; mineralization; capital expenditures.

\section{ntroduction}

"Gosha" gold mine is located in the northeastern part of the Lesser Caucasus between the rivers Asrikchay, Ahindzhachay and in the upper stream Gosha-su.

Ore field combines several promising deposits: Goshinsky, Itkyrylansky, Boyuk-Kishlaksky, Karavellyarsky, Safarlinsky, Perizamanlinsky, Oksyuzlinsky, Asrikchaysky, Gariblinsky, as well as some other deposits and occurrences.

Among these ore deposits and occurrences Goshinsky gold deposit is the most promising and has attracted the attention of foreign mining companies.

Ore deposits are represented by industrial veins of various shapes and sizes. Actually, vein formations are diabase dikes with capacity from $0.1 \mathrm{~m}$ to 3 $\mathrm{m}$ and a length of over $1 \mathrm{~km}$.

Gold is the primary valuable component of industrial veins; silver and copper have secondary importance. In northeastern zones of the industrial veins, in some intervals, there is no gold and in others, it is unevenly distributed.

Ore deposits are characterized by a complex mineral composition. There are more than 30 minerals in these ore deposits.

Among ore minerals, zones of hydrothermal alterations were found in gold veins and silicified, it is possible to recall pyrite, chalcopyrite, chalcocite, barite, koveline, malachite, azurite, and (in rare cases) native gold. Capacity of the individual zones of hydrothermal altering rocks varies from one to tens of meters [1].

Material composition and intensity of mineralization in hydrothermally altered zones and gold ore veins is very volatile. Numerous intervals that contain gold reserves of industrial importance are located in range of the same zone.

In all of hydrothermally altered areas, occurrences of gold, silver and sulfides are in phenocrysts confined to veins, vein lets or other forms of congestions. It is also possible to observe ore mineralization in hydrothermally altered host rocks.

Hypogene minerals spread in the "Gosha" gold deposit are pyrite, pyrhotite, enargite, chalcopyrite, silver, gold, sphalerite, magnetite, rutile, anatase, faded ore, cinnabar, en-timonen, realgar, orpiment and chalcocite.

Non-metallic minerals available in Gosha deposit are quartz, calcite; and the minerals found in the oxidation zones are: malachite, azurite, goethite, limonite, hydrogoethite, hydrohematite, chalcocite, kovallin, cuprite and bornite.

The main ore-forming mineral of gold mineralization is pyrite, in some areas reaching $70 \%$ of the total volume of ore. Copper minerals, mainly of chalcopyrite, make up 10 to $15 \%$ of the ore. Along with chalcopyrite and pyrite, there also are rare tiny inclusions of sphalerite in the main ore mass [2].

Identified mineralized zones and auriferous veins contained in these zones are grouped in two systems of cracks: 1) Early - Northeast; 2) Later Northwest.

Cracks in the northeastern region of the Gosha deposits are overwhelmingly filled with quartz veins, which are rich in gold reserves. In all mineralized zones, one can find quartz, rarely quartz-carbonate veins, with thin veins and phenocrysts of pyrite. Power quark lived from $0.2 \mathrm{~m}$ to $2.5 \mathrm{~m}$, and the intensity of the proto from $20 \mathrm{~m}$ to $400 \mathrm{~m}$. Conductor character forms a steep drop from $60^{\circ}$ to $90^{\circ}$. Taking into account confinement of the ore deposits in quartz veins it becomes possible to predict the prospects of the detection of industrial concentrations of gold present even in the secondary quartzite.

Very significant wives from 700 to $800 \mathrm{~m}$ characterize this mineralized zones and ore bodies. A thickness of ore bodies varies from $15 \mathrm{~m}$ to $20 \mathrm{~m}$, and in some cases, their capacity reaches up to $50 \mathrm{~m}$ from $30 \mathrm{~m}$.

Materials and methods

Geological study and research have shown that gold ore deposits require the use of specific systems development under conditions of Goshinsky deposit.

At present, the stage is characterized by insufficient rates of the development of ore deposits and of reproduction of the mineral resource base, with a low probability of discovery and development of new fields.

Therefore, a large number of mining companies strives to maintain production capacity by selecting and applying the most effective systems for the development of ore deposits. In this context, increase in the depth of ore bodies leads to the complicated conditions for mining activities, which entails a significant increase in the specific capital expenditures. This in turn requires a search for new ore mining methods.

It is important to use efficient systems for the development of one of the promising areas of underground mining, ores of average capacity. Economic 

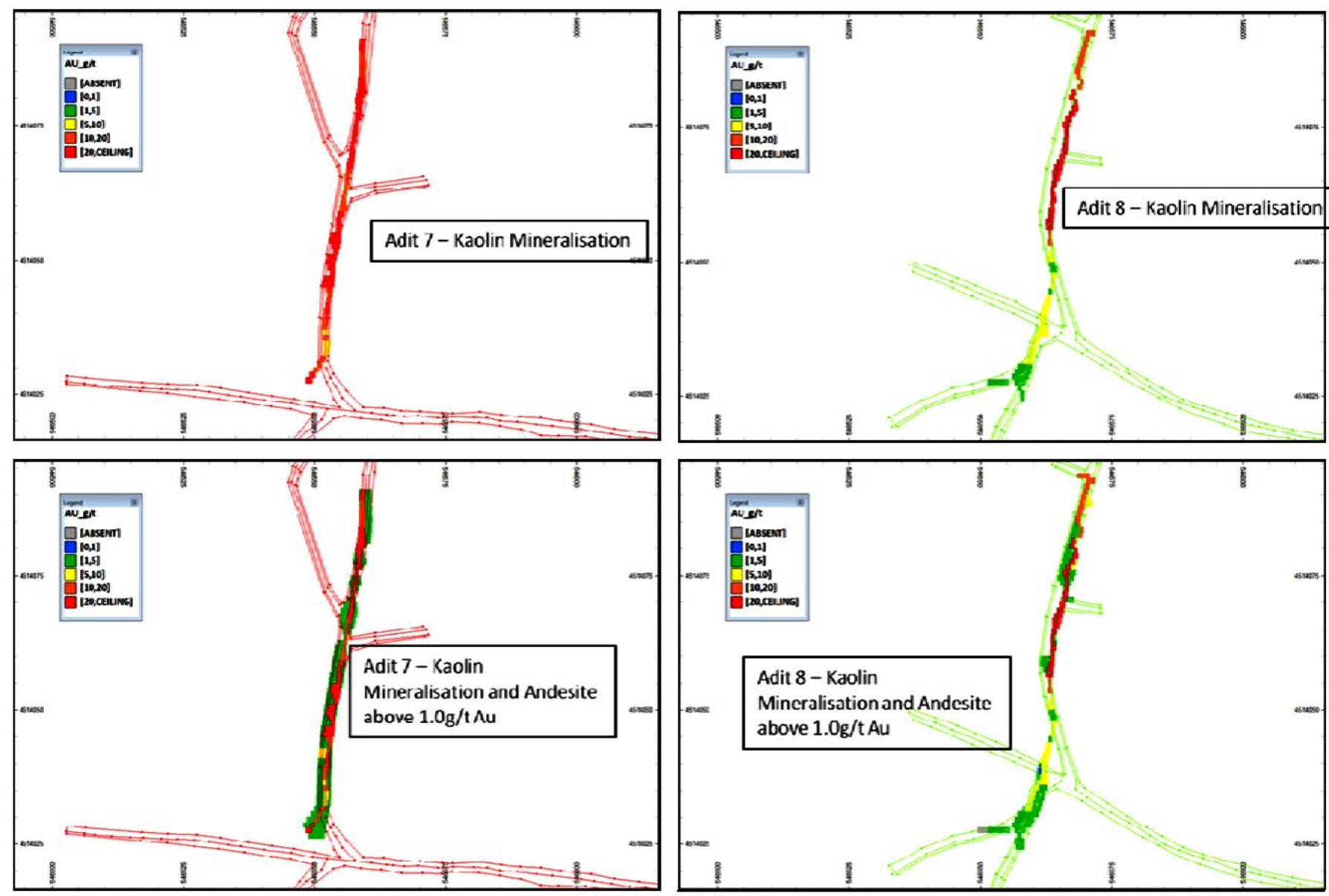

Figure 1. Conceptual model of the useful component amount.

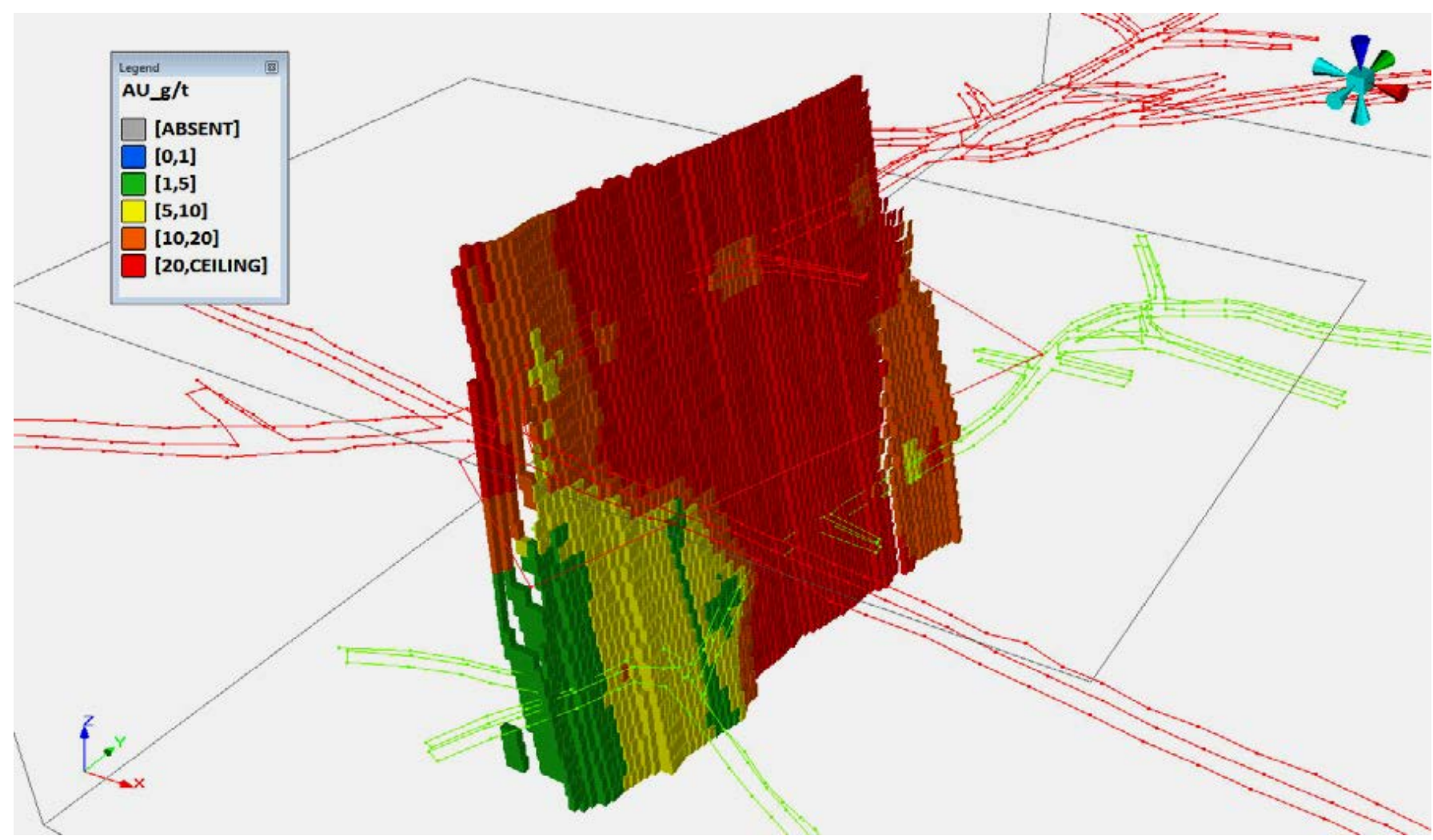

Figure 2. Kaolin isometric Projection Model. 
criteria for these systems focus on earning maximum profits at minimum costs spend at 1 tone of balance reserves. This requires technologies providing high efficiency of mining operations [3-5].

In the literature, there are more than 200 varieties of the main systems of underground mining of ore deposits.

There is a number of their classifications (N. I. Trushkov, R. P. Kaplunov, N. A. Starikov, V. R. Imenitov and so on). The most common is M. I. Agashkov classification based on symptom status of clearing space in the period [6, 7].

Since 2009, international mining company has been spending more detailed exploration works on Goshinsky gold deposit. These works has identified several rich ore zones and conducted repeated testing for known industrial horizons. In 2010, 5 wells were dug with more than $350 \mathrm{~m}$ of adits.

Reserves in the Gosha deposit consist of gold veins with little thickness, grouped into two sets, which lengthen to each other perpendicularly. In this research, attention was on one point. The vein consists of the mineralized quartz - pyrite - caolinite mass, which is located inside the weak mineralized andezites. Authors developed and prepared conceptual model according to the amount of ore and a useful component for the mineralized area section of area number 13 and around 7 and 8 stonlays on the base, which exists according to the deposit (Fig. 1).

According to the amount of ore and mineral components up model No. 7 to No. 8, mining passages were extrapolated on $15 \mathrm{~m}$. The length of modeled productive layer reflects the length of productive layer in the crossings of both mining passages. The coverage of Kaolin model is presented in isometric projection shown in the Fig. 2.

Authors considered following development systems for exploitation of gold deposits, which have complex geological and finely kaolin mineralization [6-8]:

- Wells with open face, top-down or vice versa;

- Top-down cutting and filling;

- Development system based on shrinkage of ore in cleansed space;

- Benched development system along the dip;

- Washing of ore with high pressure water;

- Cutting of ore with chain mechanisms;

- Method of mechanical drilling with a notch in the side of ore rocks by cutting and filling.

Authors evaluated and conducted general characteristic studies, the results of which are in Table 1.

Following criteria were used for selection of optimal development systems of Goshinsky gold deposits:

1. The productivity rate of the mine throughout its operational life is 45,000 tons per year (120 tons per day).

2. Ores of industrial importance are located in kaolin veins. Particularly, in quartz-pyrite which is concentrated in kaolin mass.

3. Initial useful component of the ore lies close to the vertical slope of the ore zone with width from 0.25 meters to 2.5 meters, and angle of descent from $75^{\circ}$ to $85^{\circ}$.

4. Suspended and lie foundation wall consist of silicified andesite.

5. Available sizes of galleries and distance between the horizons:

a) Approximately $2.2 \mathrm{~m}$ (height) $\times 2.2 \mathrm{~m}$ (width).

b) In galleries № 4, 7 and 8, the distance between the levels is $40 \mathrm{~m}$;

6. Necessity for verifying possible contours of development of ore zone: Approximately 70 (length) x 70 (height).

7. According to the estimation, capacity in the area 13 is from $250 \mathrm{~m}$ to $400 \mathrm{~m}$ depth.

8. There are many other industrial potential mineralization zones in the Goshinsky system.

While selecting our proposed system of development for the mine, besides the criteria mentioned above, it is important to take into consideration such factors as: location, staff's skills, climate, topography, characteristics of a worked out ore, requirement for filling spaces left empty after exploitation, ore loss, impoverishment, maintenance expenditure, ventilation, drainage, flexibility, and so on.

A conducted research concluded, taking into account all necessary given criteria and mining conditions for Goshinsky deposit, that the most effective field development system is "Wells with open face, breaking of ore by blast holes, from the top to bottom." The most efficient version of the proposed system development is provided below. Main parameters and criteria for the effective variant of the proposed system design are given in Table 1.

The key factor in selection of excavation system for the development of the narrow ore veins is assurance of minimum impoverishment of the ore zone [9].

Upon considering the size of the equipment working area, their width should be greater than the width of ore. Otherwise, it may lead to the impoverishment of the ore zone. This is especially dangerous in the development of 13 th ore zone as narrow ore bodies are richer with useful component. 
Table 2. Characteristics of the proposed system "Wells with open face, breaking of ore by blast holes, from the top to bottom" SWOT analysis.

\begin{tabular}{|c|c|c|c|}
\hline Strengths & Weaknesses & Expected & Expected dangers \\
\hline High Productivity & Impoverishment and ore loss & Diversion of waste (underground) & $\begin{array}{l}\text { Sort backfill material (source) and path } \\
\text { of delivery }\end{array}$ \\
\hline Small requirements of preparatory drifts & $\begin{array}{l}\text { Requirement of ensuring of oblique } \\
\text { entrance }\end{array}$ & Numerous land developments & $\begin{array}{l}\text { in the scheme of the deve lopment of } \\
\text { "top-down" ore loss in columns }\end{array}$ \\
\hline Requires for low skill level & Ineffective use of basic equipment & $\begin{array}{l}\text { When laying worked out spaces } \\
\text { preservation of columns is unintended }\end{array}$ & $\begin{array}{l}\text { Need to choose an intermediate } \\
\text { distance in the lower layers }\end{array}$ \\
\hline \multirow[t]{3}{*}{$\begin{array}{l}\text { There is no need for the use of } \\
\text { classified systems }\end{array}$} & Rational flexibility In tracing of ore & & $\begin{array}{l}\text { In kaolin environment "top down" a } \\
\text { problem of deep drilling can appear }\end{array}$ \\
\hline & High level of capital expenditure & & \\
\hline & $\begin{array}{l}\text { Inside of backfill materials and potential } \\
\text { loss of ore (bottom up) }\end{array}$ & & \\
\hline
\end{tabular}

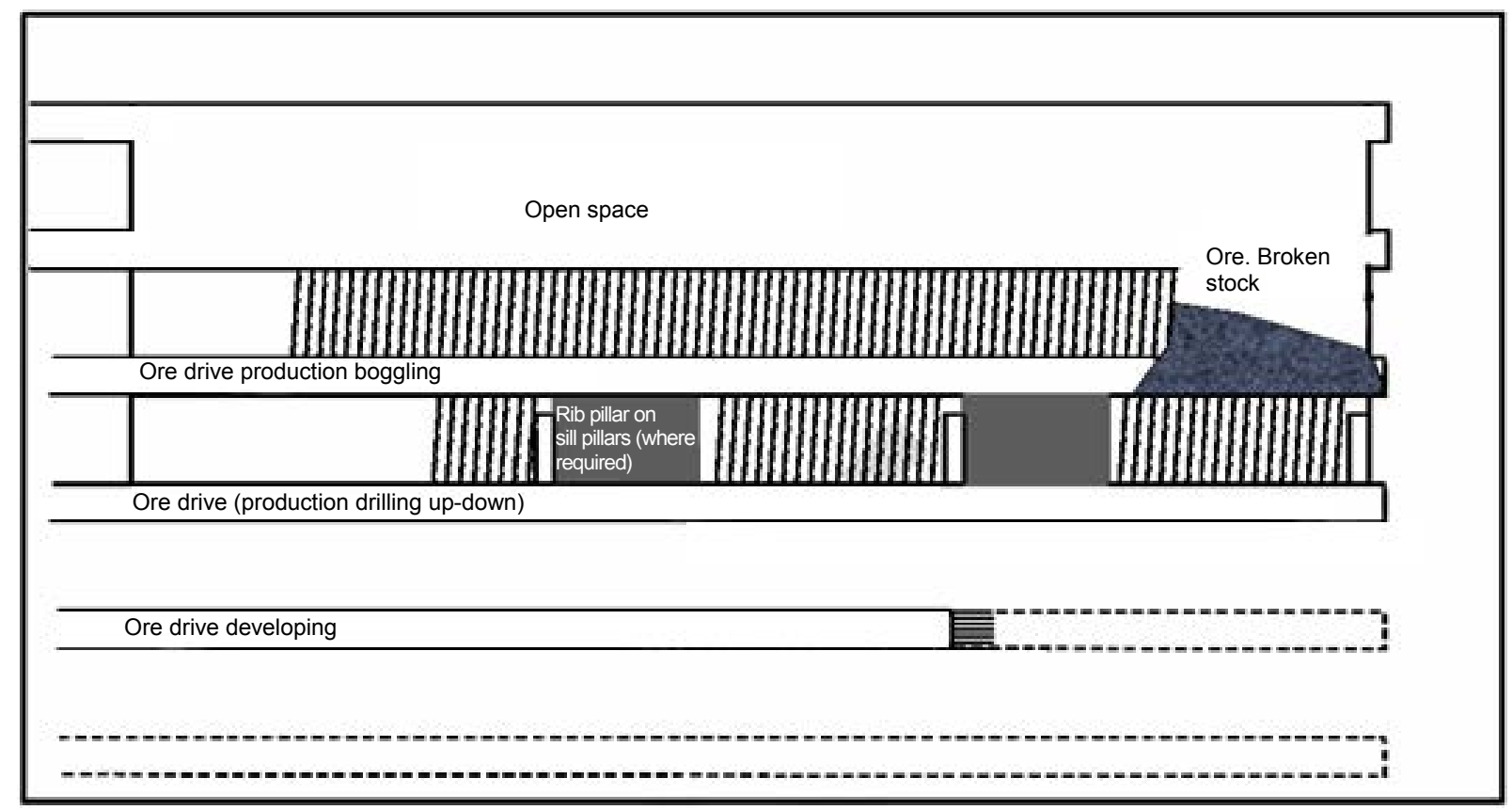

Figure 3. Proposed version of development systems - "Wells with open face, breaking of ore by blast holes, from the top to bottom."

Results

For Goshinsky gold deposit choosen development system is "Wells with open face, breaking of ore by blast holes, from the top to bottom" for Goshinsky gold deposit. Table 2. "Wells with open face, breaking of ore by blast holes, from the top to bottom"- SWOT analyze has been given.

In Fig. 3, a schematic diagram of the embodiment illustrates field development system, "Wells with open face, breaking of ore by blast holes, from the top to bottom."

The above-stated development system for the ore zones should be implemented in the following sequence:

1. Preparations of ore drifts. The distance between the developed drifts depends on the change in vertical position of the zone № 13. Intermediate distance between drifts can be changed based on experience; nevertheless, it will probably be no more than $5 \mathrm{~m}$. First developed horizons will be based on the development of the first block. For conducting mining operations and providing sufficient width for penetration, drilling along the drift should remove rocks.

2. Downward drilling of deep wells between horizons;

3. Preparation of cutting holes;

4. Loading wells in stages; loading and blasting (usually $2-8$ per explosion of the round);

5. Loading and unloading of exploded materials

6. The circuit design for each horizon provides takeaway materials from treatment areas from top to bottom. There are also possible options for loading and unloading at a distance. Alternatively unprocessed materials can be stored in the treatment areas. During the lower penetration of the treatment areas, the ore will be fed down. In this case, it will be possible to collect it from the subsurface. Only with the sole treatment units for cleaning horizons require loading in the distance.
Columns between the chambers or over drifts (over orts) provide leave in place.

7. Repeating of the process.

Discussion

Filling of the developed gap is not required in this proposed development system. Cleaning area progresses downward, trailing spaces that remain working in the field of cleaning may create a risk to people and equipment. If it is necessary to keep the columns between cameras and streck over (overlapped) for the geotechnical reasons, they can be placed in narrower mineralization zones being with less amount of the useful component.

Our proposed options for development systems Goshinsky gold deposit fully meet the conditions of natural and technological fields and can be applied to other ore deposits of Azerbaijan and neighboring countries with similar mining and geological conditions.

\section{REFERENCES}

1. 2003, Geologiya Azerbaydzhana [Azerbaijan Geology], Baku. vol. 6, 576 p. 2. 2005, Mineral'no-syr'evye resursy Azerbaydzhana [Mineral-raw material resources of Azerbaijan], Baku, 807 p.

3. Starikov N. A. 1947, Sistemy razrabotki mestorozhdeniy [Mining systems], Moscow, $326 \mathrm{p}$.

4. Trushkov N. I. 1947, Razrabotka rudnykh mestorozhdeniy. Podzemnye raboty [Development of ore deposits, Underground work], Moscow, vol. 2, 546 p.

5. Mamedov Sh. N., Mukhtarov G. G. 1966, Effektivnye sistemy i tekhnologiya razrabotki zhil'nykh mestorozhdeniy Azerbaydzhana [Effective systems and development technology of core fields in Azerbaijan], Baku, 205 p.

6. Agashkov M. I., Malakhov G. M. 1996, Podzemnaya razrabotka rudnykh mestorozhdeniy [Underground mining of ore deposits], Moscow, $636 \mathrm{p}$.

7. Afandiyeva Z. J., Osmanov M. B. 2012, Povtornaya razrabotka Kedabekskogo zolotomedno-kolchedannogo mestorozhdeniya otkrytym sposobom [Kedabek gold-copper-pyrite deposit open pit is in the redevelopment]. Gornyy zhurnal 
[Mining Journal], Moscow, no. 4, pp. 36-37.

8. Afandiyeva Z. J. 2008, Otsenka vliyaniya fizicheskikh svoystv gornykh porod

na sistemu razrabotki samoobrusheniya rudy [Assessing the impact of the physical properties of rocks on the development system caving ore]. Gornogeologicheskiy zhurnal [Mining and Geological Journal], no. 1-2, pp.17-21.

\section{Эфендиева Зарифа Джахангир,}

кандидат технических наук, доцент

efendi2005@rambler.ru

Азербайджанский государственный университет нефти и промышленности

Азербайджан, Баку, пр-т Азадлыг, 20

Османов Мохаммад Баба

советник по горному делу

moqamed57@mail.ru

Горнодобывающая компания “АИМкЛ”

Азербайджан, Баку, st. H. Alasgerov, 16
9. 2000 , Instruktsiya po bezopasnomu vedeniyu gornykh rabot na rudnykh i nerudnykh mestorozhdeniyakh, ob'ektakh stroitel'stva podzemnykh sooruzheniy, sklonnykh i opasnykh po gornym udaram [Instructions for safe mining operations on metallic and nonmetallic deposits of underground construction sites, dangerous and prone to rock burst], Moscow, $91 \mathrm{p}$.

\section{Afandiyeva Zarifa Jahangir}

Associate professor

efendi2005@rambler.ru

Azerbaijan State University of Oil and Industry

Baku, Azerbaijan Republic

Osmanov Mohammad Baba,

Advisor on mining companies

moqamed57@mail.ru

Mining Company AIMKL

Baku, Azerbaijan Republic 